\title{
Making the best of Brexit
}

\author{
In the post-Brexit era, Britain must rapidly harmonize national and European law, secure unfettered access to global \\ talent and address funding shortfalls to ensure continued leadership in the life sciences.
}

Fi: or British biotech, it is the best of times and the worst of times. On the one hand, hopes are high that the UK life science industry has government backing to maintain its leadership position in Europe. On the other, there is skepticism as to whether the nation's political leaders can negotiate an agreement with Brussels to continue access to the single market. In the next seven months, the government must allay concerns that Brexit will leave the country open to economic disruption, customs delays and compliance issues. It must ensure that the flow of skilled talent to scientific institutions and companies remains unencumbered. And it must compensate for the massive funding shortfalls faced by researchers and enterprises due to the country's withdrawal from European Union (EU) programs.

On 31 January, Britain formally announced its departure from the EU, bringing to an end three years of political infighting and stalemate since the public referendum. There remain nine months of negotiation with Brussels to determine whether Brexit will be soft (that is, an agreement in which Britain remains closely aligned to the EU single market), hard (an agreement in which Britain gains only limited access to the EU market) or no deal (no agreement and no access to the EU market except via specific trade deals).

Brexit has cast a long shadow over the country's financial sector, contributing to dwindling interest from investors on the main market or the Alternative Investment Market. UK biotechs now regard the United States, and Nasdaq in particular, as their primary source for accessing public funding. At the same time, the post-referendum gloom has resulted in a multi-year, precipitous drop ( 20\%) in the UK currency (pound sterling) against both the US dollar and the euro, with both positive and negative consequences.

On the upside, the lower pound may have contributed to a boom in sterlingdenominated venture investment. According to data from information provider Informa provided to the UK BioIndustry Association, the country's biotech sector attracted $\sim \$ 870$ million in risk capital last year, including $\$ 590$ million in series B round financings - a record-breaking amount. In 2019, UK biotech attracted nearly three times as much venture capital as the sectors in France or Germany.

The downside is that UK biotech firms have become increasingly attractive targets for acquisitive foreign firms. Like a universal Black Friday discount, a fire sale of UK assets has been underway since 2016, including Takeda Pharmaceutical's buyout of Shire, Boston Scientific's takeover of BTG and Biogen's acquisition of gene-therapy pioneer Nightstar Therapeutics.

If Britain is to ensure that these companies are replaced and support the 220,000 jobs in biotech, the newly re-elected Conservative party must live up to its election promise of making "the UK the leading global hub for life sciences."

A first step to this goal is maintaining continuity of trade with Europe when Brexit is implemented on 31 December. Without continuity, Britain faces shortages, customs delays at ports, and loss of business. According to one government estimate, this could threaten up to 28 million drug packets entering Britain every month from the EU. Officials have been scrambling to secure freight capacity on cross-Channel routes to avoid delays and ensure express delivery of biologics requiring a cold chain. UK biopharmaceutical firms have also been advised to stockpile an extra six weeks of products on top of their normal reserves.

Ironically, the government's current strategy for minimum trade disruption is to harmonize UK and EU law via a massive program of legislative duplication. This will involve a painstaking process of copying each EU law and rebranding it as British. This will give the government the legal mechanisms to explore its new freedoms in tweaking national laws to incentivize biotech - for example, re-examining its implementation of Directive 2001/18/ $\mathrm{EC}$ and EU rules on gene-edited crops or fine-tuning the European General Data Protection Regulation to facilitate the use of artificial intelligence in biomedicine.

Another important goal will be to ensure UK biotech retains access to skilled talent. This is a concern as Britain has some of the highest visa processing fees in the world and UK biopharmaceutical companies are already struggling to fill senior positions. The new points-based immigration plan announced last month reduces fees for $\mathrm{PhD}$ applicants, but it is unlikely to be enough.

At present, the UK government pays lip service to research and innovation. It has replaced three science ministers in just the past year. Since 2016, research investment has fallen as a percentage of gross domestic product to $1.67 \%$ - well behind France (2.2\%), Germany (3\%), the United States (2.8\%), Slovenia (1.85\%) and the Czech Republic (1.79). This trend must be reversed if the country is to retain any sort of reputation as an innovative economy. Of particular concern is the $\sim \$ 1.2$ billion annual hole in funding facing researchers if no way can be found to participate in the 2021-2027 Erasmus and Horizon Europe programs.

The government's record on business is better. Over the past decade, biotech and other UK industry sectors have benefitted from taxation incentives offered to investors who put money into venture capital trusts (VCTs) to spur enterprise creation. After Brexit, sans EU rules forbidding sectorspecific promotion, life-science-specific VCTs can be created by British lawmakers to build industry momentum.

Finally, as this journal has previously highlighted, the UK National Health Service is a resource to collect and analyze data nationally, to implement wide-scale clinical studies, and to work with innovative companies in precision medicine and machine-learning-supported decisionmaking. The success of initial efforts to leverage data from the UK Biobank demonstrates that electronic networking and data sharing can be extremely powerful.

Brexit offers UK biotech a chance to escape EU regulatory limbo. But to make the best of the current situation, government must put money where its mouth is. This will be especially true if stepping away from Europe means stepping away from European research funding.

Published online: 9 March 2020 https://doi.org/10.1038/s41587-020-0463-X 